\title{
Portrety ludzi i zwierząt w powieści detektywistycznej Marty Matyszczak Tajemnicza śmierć Marianny Biel
}

Human and animal portraits

in a detective novel by Marta Matyszczak

Tajemnicza śmierć Marianny Biel

Abstract: The article points to the advantages of utilizing books chosen and read by students during lessons of Polish. As illustrative example here serves Tajemnicza śmierć Marianny Biel written by Marta Matyszczak, a contemporary detective novel, published in 2017, partially narrated from the perspective small invalid mongrel. The novel's structure is conducive to discussion of detective stories in didactic work, showing the "Silesian" features of the novel's characters, and analyzing their seemingly superficial characters. On the basis of the novel, the subject of animal studies may be raised: the animality of the relationship between humans and animals. The article draws attention to the importance of the animal issues in humanities, going beyond the understanding thereof as "the animality of human nature." It emphasizes the essence of giving voice to the animals and empowering them, without trying to "humanize" them.

Keywords: detective novel, high school, Polish lessons, youth reading, animal studies

We współczesnej szkole uczniowie nie mają wielu okazji, aby czytać kryminały, choć eksperci wskazują, że nurt literatury kryminalnej dla dzieci i młodzieży bardzo się rozwija, a zainteresowanie tym rodzajem powieści znacząco wzrasta (Czubaj, 2007, s. 73). Pozytywny wpływ lektur tego typu na późniejszy poziom kształcenia kompetencji czytelniczych, rozwoju zainteresowań, osobowości jest opisywany w wielu pracach — zarówno z zakresu psychologii i pedagogiki, jak i w pracach literaturoznawczych (Sadzikowska, 2015, s. 451). Powieści kryminalne i detektywistyczne pogłębiają zainteresowanie światem i rzeczywistością, potęgują ciekawość, inspirują do działania oraz do logicznego myślenia (Cieślikowski, 1975, s. 52). Bardzo często ich autorzy kładą nacisk na uczu- 
cia pozytywne, takie jak przyjaźń, miłość, a także kształcą młodego czytelnika moralnie - propagują wiarę w zwycięstwo dobra nad złem. Jeśli powieści detektywistyczne są tak popularne wśród młodzieży, to warto rozwijać czytelnicze zainteresowania uczniów, aby zachęcić ich do lektur obowiązkowych. Zbrodnię $i$ kare Fiodora Dostojewskiego można analizować jako thriller zawierający elementy powieści kryminalnej, Imię róży Umberta Eco - jako reprezentację powieści kryminalnej, w Procesie Franza Kafki zaś warto podkreślić wątek kryminalny.

Wydaje mi się, że atrakcyjną propozycją lektury adresowaną do młodzieży szkolnej może być Tajemnicza śmierć Marianny Biel autorstwa Marty Matyszczak, powieść wydana w serii Kryminał pod Psem w 2017 roku. Wybieram ją nie tylko dlatego, że jej struktura znakomicie nadaje się do "podręcznikowego" omówienia wyznaczników kryminału, jest pełną humoru opowieścią o odkrywaniu prawdy umieszczoną $\mathrm{w}$ środowisku, które uczniom jest po prostu bliskie (śląskie familoki), ale przede wszystkim dlatego, że jej fragmenty uwzględniają perspektywę psa, wiernego towarzysza detektywa. Tę cechę uznaję za szczególnie istotną w przybliżeniu młodym czytelnikom kategorii animal studies oraz po prostu uwrażliwiania ich na istoty nie-ludzkie.

Zwierzęta od zawsze towarzyszyły człowiekowi (Berger, 1999, s. 7), choć zwykle były mu podporządkowane (Nowak, 2009). Widziano w nich źródło pożywienia, transportu, siły roboczej, ale także obiekt magiczny czy wręcz boski. Niezależnie od pełnionej przez zwierzę „,roli”, człowiek był świadomy, że nie jest w stanie istnieć bez niego. XIX-wieczna rewolucja przemysłowa znacząco wpłynęła na postrzeganie kwestii współbycia zwierząt i ludzi. Odtąd istota nie-ludzka utraciła swoje magiczne korzenie, stając się potrzebnym elementem w trybach przemysłu. Rozwijająca się technika sprawiła, że człowiek przeniósł się ze wsi do miasta, w którym brakowało naturalnych przestrzeni dla zwierząt. Spadło ich zapotrzebowanie jako siły roboczej. Mięso zwierzęce, w przeszłości potrzebne, by przeżyć, obecnie jest powszechnie dostępne i nie wzbudza refleksji, skąd pochodzi, a magię i mistycyzm świata zwierząt postrzega się już wyłącznie w aspekcie komercyjnym. Człowiek stracił szacunek dla zwierzęcia, a ono samo zostało pozbawione tajemniczości i nie reprezentuje już boskiego bytu.

W 1975 roku ukazała się książka australijskiego filozofa i etyka Petera Singera Wyzwolenie zwierząt, która została uznana za "biblię” Ruchu Wyzwolenia Zwierząt. Wyłożone w niej postulaty stały się podstawą do walki o prawa zwierząt, a jednocześnie wyznaczyły kierunki rozwoju animal studies. Autor, głosząc hasło wyzwolenia zwierząt, zaznacza, że będzie ono także wyzwoleniem człowieka.

Studia nad zwierzętami, animal studies, wpisują się w nurt posthumanistyki, krytykującej centralną pozycję człowieka w świecie i ukazującej, że egzystencja w rzeczywistości zbudowanej na innych zasadach jest nie tyle możliwa, ile wręcz nieuchronna. Jednym z postulatów posthumanistyki jest przygotowanie ludz- 
kiej świadomości na nadchodzące zmiany społeczno-polityczne, czyli demokratyzację i liberalizację. Filozofia ta obejmuje różne dyskursy, głównie krytyczne (Domańska, 2006, s. 18), wskazuje także problem walki o władzę: kryzys humanizmu burzy wizerunek człowieka - władcy świata, i jest bodźcem do uczynienia $\mathrm{z}$ niego jednego z wielu równoważnych podmiotów żyjących na Ziemi. Choć antropocentryzm deklaruje ideę troski o ,inne” byty i ich obronę, to w efekcie traktuje je przedmiotowo i nie zezwala na ich autonomię (Domańska, 2006, s. 14). Poszukuje się nowego, bardziej egalitarnego i sprawiedliwego porządku, antropocentryzm „odchodzi do lamusa”. Prowadzi to do konieczności podjęcia refleksji dotyczącej przenikania się świata ludzkiego i zwierzęcego, a nawet roślinnego (Nowak, 2009). Na kanwie animal studies powstała zoofilologia - domena odkrywająca niedostrzeżone dotąd związki między techniką pisarską czy estetyką i światem zwierząt (Nawarecki, 2011, s. 16).

Studia nad zwierzętami możemy postrzegać także jako próbę poszukiwania odpowiedzi na pytanie, jak człowiek powinien współistnieć $\mathrm{z}$ innymi gatunkami i na jakich zasadach powinny się opierać wzajemne relacje między tym, co „ludzkie”, a tym, co "nie-ludzkie”. Relacje zwierzę - człowiek to jedna z podstawowych, ludzkich opowieści, gdyż ludzie wchodzą w różne relacje z nie-ludzkimi zwierzętami (Kurek, Maliszewski, 2011, s. 11). Umberto Eco pisał:

Zwierzęta zawsze mówiły w mitach i w bajkach. Te antropomorficzne fantazje dowodzą, że ludzie zawsze byli zafascynowani swymi nieodgadnionymi towarzyszami podróży, kryjącymi w sobie obietnicę objawienia niepokojących, ale i oświecających prawd.

Eco, 2009, s. 142

Za jeden z celów animal studies uznaje się walkę o radykalną zmianę sytuacji zwierząt: upodmiotowienie ich, ograniczenie i zaprzestanie ich eksploatacji oraz zadawania cierpień. Analizując sytuację zwierząt, można ją przyrównać do położenia innych grup uciskanych - niewolników, czarnoskórych, kobiet (Nowak, 2009). Zasadnicza różnica między ludźmi a nie-ludźmi polega jednak na tym, że zwierzęta nie są w stanie stawić skutecznego oporu ani wyartykułować swoich postulatów i pragnień - to my musimy przemówić w imieniu tych, którzy mówić nie umieją (Singer, 2004, s. 11).

Poszukiwanie innych od antropocentrycznego kierunków postrzegania świata poskutkowało powstaniem nowej przestrzeni dla nowych dyskursów. Jednym z nich jest zoofilologia, która pozwala dostrzec perspektywę zwierząt, ich punkt widzenia. Za cel stawia sobie przekształcenie antropocentrycznego pytania: jak literatura przedstawia zwierzęta? Jak wygląda literatura z perspektywy zwierząt? Czy zwierzęta egzystujące $\mathrm{w}$ tekście wiedzą więcej niż człowiek? (Nawarecki, 2011, s. 16).

Przywołane przykłady wskazują wspólne obszary doświadczenia, podkreślają miejsca krzyżowania się biografii ludzi i zwierząt, ale ich zwolennicy kła- 
dą nacisk na szacunek wobec różnorodności zwierzęcych aktorów w więcej niż „ludzkim świecie”. Zezwolenie zwierzętom na bycie innymi stanowi warunek podejmowania prób mówienia $\mathrm{z}$ ich perspektywy lub w sposób uwzględniający ich interesy (Barcz, Łagodzka, 2015, s. 11). Celem studiów nad zwierzętami jest zwrócenie uwagi na doniosłość zwierzęcej problematyki w humanistyce, wykraczającej poza rozumienie jej jako „zwierzęcość ludzkiej natury motywu literackiego czy ikonograficznego" (Barcz, Łagodzka, 2015, s. 11).

Zoofilologia oraz studia nad zwierzętami poszukują nowych sposobów myślenia o zwierzęciu i zwierzęcości - innego niż zoologiczne uprzedmiotowienie czy etyczne współczucie (Lestel, 2015, s. 17). Wciąż trudno jest postrzegać zwierzęta, szczególnie te podobne do ludzi w zachowaniach i potrzebach, poza modelem ludzkiej umysłowości i przeżywania świata - a tylko do tego modelu mamy dostęp. $\mathrm{W}$ tej kategorii antropomorfizacja jako próba oddania głosu zwierzęciu jest naturalna, ale niemożliwe okazuje się potwierdzenie jej trafności.

Zmiana zasad współbycia ze zwierzętami staje się coraz bardziej nagląca i nieuchronna, niemożliwa jednak bez zmiany sposobu myślenia. Coraz częściej oddaje się głos współtowarzyszom ludzkiego życia, dotąd „niemym”. Czas pokaże, czy próby prowadzenia nowego dyskursu zakotwiczą się w dyskusji i staną się normą (Żychliński, 2015, czwarta strona okładki).

W powieści Tajemnicza śmierć Marianny Biel na pierwszy plan wysuwa się trójka bohaterów. Szymon Solański, założyciel i jedyny członek agencji detektywistycznej „Solan”, jest samotny, aspołeczny, zmęczony życiem i zblazowany:

Tak naprawdę nie dawała mu spokoju samotność Marianny Biel. Bolała go do żywego. Ponieważ on sam był równie opuszczony jak aktorka. Tyle że on w pełni sobie na swoją samotność zasłużył.

Matyszczak, 2017, s. 65

Przed kilkoma laty utracił $\mathrm{w}$ pożarze ciężarną żonę - wypadek pozostaje dla niego nieprzepracowaną traumą. Jednym z elementów ubogiego wystroju jego kawalerki jest fotografia Joanny Solańskiej, na którą Szymon spogląda $\mathrm{w}$ trudnych chwilach. Po tej tragedii porzucił uwielbianą niegdyś pracę w policji i popadł w marazm. Nie widząc jednak dla siebie miejsca w zawodzie niepowiązanym z pracą śledczą, założył agencję detektywistyczną. Choć pozostaje ona jedynym źródłem marnego dochodu, Szymon niechętnie przyjmuje zwyczajne zlecenia, a zdradzane żony szukające "haka” na niewiernego męża odprawia $z$ kwitkiem. Dopiero przygarnięcie psa Gucia zmienia jego monotonne i szare życie:

Z pojazdu wyskoczył sięgający kolana czarny kundel z rudą krawatką i klapniętymi uszami. 
- A to kto? - Róża wybałuszyła oczy.

- Gucio - dokonał prezentacji Solański. Pomyślał, że w końcu przybył mu drugi przyjaciel, do którego będzie mógł zwracać się po imieniu.

Charakter Solańskiego określają jego empatia i wrażliwość na losy zwierząt. Kiedy dowiaduje się, że stary pies bez nogi nie ma szans na prawdziwy dom, decyduje się na jego przygarnięcie, nie zważając na swoją beznadziejną sytuację finansową i mieszkaniową. Nie mając praktycznie z czego żyć, regularnie wspiera chorzowskie schronisko, licytując rzeczy na bazarku (kubek za sto złotych, który natychmiast obtłukuje Gucio).

Szymon Solański jest chudym, patykowatym i wysokim mężczyzną. Ma długie czarne włosy, zarost i szare oczy. Gucio opisuje go w ten sposób:

Solański może i był przystojny, ale, jak to mówią, na swój sposób. Czyli jednym mógł się podobać wysoki, chudy, czarny i zarośnięty mruk, innym wręcz przeciwnie.

Detektyw jest właścicielem garderoby składającej się z trzech czarnych wymiętych podkoszulków, dżinsów i skórzanej kurtki. Nigdy nie ubiera się odpowiednio do pogody, co odzwierciedla jego beznadziejną sytuację finansową.

Trudno stwierdzić, czy Solańskiego można uznać za typowego protagonistę powieści kryminalnej. Obecnie ten typ literatury zawiera tak rozbudowany kanon postaci - od detektywów rozpoczynając, a na profilerach czy dyplomatach kończąc, że „typowy” śledczy z wolna przestaje już nim być. Z pewnością Szymon jest postacią wielopłaszczyznową, z traumatycznymi doświadczeniami życiowymi, o trudnym charakterze, jednak dzięki temu, a także wskutek przeciwieństw życiowych, których doświadcza, może być bliski zarówno zwykłemu dorosłemu czytelnikowi, jak i młodzieży. Wydaje się, iż pomimo założenia, że Solański jest głównym bohaterem powieści, bez wsparcia w postaci kundelka Gucia i swojej nieokrzesanej przyjaciółki Róży nie zaciekawiłby odbiorcy.

Róża Kwiatkowska - poza psem Guciem jedyna przyjaciółka Solańskiego, pracuje jako dziennikarka w „Chorzowskich Nowinach”. Należy do osób, które prześladuje notoryczny pech, powodujący zabawne (nie dla samej zainteresowanej) wydarzenia:

W życiu Róży Kwiatkowskiej nawet imię i nazwisko było spartolone. Tylko z pozoru niewinny żarcik rodziców, uskuteczniony trzydzieści dwa lata temu w chorzowskim Urzędzie Stanu Cywilnego, ciągnął się za nią całe życie, jak smród po gaciach. Absurd sytuacji ujawniał się w pełni dopiero wtedy, gdy zobaczyło się Różę na własne oczy. Kwiatkowska z kwieciem wspólnego nie 
miała nic. A już na pewno nie z różami. No, może co najwyżej z bodziszkiem cuchnącym bądź wężymordem.

Bohaterka ta zadziwia swoją niepospolitą pospolitością — nie grzeszy urodą, figurą ani ogromnym ilorazem inteligencji. Jest zwykłą, bardzo lojalną kobietą z wielkim sercem i mnóstwem kompleksów, niespecyficzną dla bohaterek literackich. Jej skomplikowany charakter i brak dystansu do siebie sprawiają, że trudno z nią współpracować, zwłaszcza gdy bezustannie pakuje się w tarapaty:

Kwiatkowska w przeszłości grzeszyła masą, ale nie urodą. I tak pozostało do dziś. Tłuste, mysie włosy oblepiały ciasno jej czaszkę, kartoflowaty nos świecił niczym latarnia morska, a ubranie (Solański był o tym przeświadczony) Róża musiała kupić sobie w sklepie $\mathrm{z}$ namiotami.

Róża ma bardzo wybuchowy charakter, prócz tego nie stroni od alkoholu, co w połączeniu z jej niezdarnością i brakiem wyczucia prowadzi do wielu komicznych zdarzeń. Jest kobietą o wielu twarzach - każda z nich jednakowo nieudolna. Ma natomiast niewiarygodny wręcz talent do popadania w żenujące sytuacje:

Róża sunęła od krawędzi do krawędzi biurka, ślizgając się na obrotowym krześle. Chwiała się na wszystkie strony. Wywijała rękami na wszystkie strony, a sadełko zwisające jej z ramion trzęsło się rozkosznie. Darła się przy tym wniebogłosy, niczym te wszystkie głuchoty z telewizji próbujące udowodnić, że mają talent albo inny x factor. Aż dziw, że szyby w oknach nie popękały od tego fałszu. Jej akcent bardziej przypominał rumuński niż angielski. W każdym razie pozostawiał wiele do życzenia. W repertuarze miała też najwyraźniej piruety, co postanowiła zaprezentować.

Jako ambitna dziennikarka, bohaterka pisze duży i ważny tekst o morderstwie jej sąsiadki z kamienicy, kobiety, której, jak się okazuje, właściwie nie znała. Sprawa artykułu, połączona $\mathrm{z}$ nieoczekiwanym powrotem dawnego przyjaciela, daje początek zwariowanej i zabawnej historii.

Kwiatkowska wchodzi w skład trójki głównych bohaterów powieści kryminalnej. Ten typ literatury za najważniejszą uznaje zbrodnię - to na niej budowana jest fabuła powieści, na niej się zaczyna i kończy. Przestępstwo sprawia, że czytelnik chce poznać zbrodniarza, niejako uczestnicząc $w$ procesie śledztwa. Efektem jest wysunięcie na pierwszy plan nie ofiary czy mordercy, lecz osoby prowadzącej dochodzenie. Mówiąc o bohaterkach powieści kryminalnej, należy zaznaczyć, że historia ich pracy zawodowej (lub czasem jej braku) odgrywa zna- 
czącą rolę, stanowi bowiem świadectwo stereotypów, z jakimi muszą się zmagać (Darska, 2011, s. 12). Jako postaci, detektywki są mocno zdeterminowane płciowo - wszakże zbrodnia i powiązane z nią obszary wciąż uznaje się za typowo „męskie”.

Bohaterki powieści kryminalnych nie są superkobietami. Mają wiele problemów związanych z codziennością, z życiem osobistym, odczuwają lęk i bezradność, próbując sprostać wyzwaniom życiowej rutyny. Nie przeszkadza im to jednak stać się mistrzyniami w typowo męskiej roli.

Poruszając kwestię kobiecych bohaterek w powieści kryminalnej, zwykło się pytać pośrednio o miejsce kobiety w społeczeństwie oraz funkcje literatury popularnej w przełamywaniu stereotypów (Darska, 2011, s. 12). Bernadetta Darska twierdzi, że kryminał należy do najbardziej wyemancypowanych gatunków w literaturze popularnej, a jego rewolucyjny wymiar dotyczy zarówno mężczyzn, jak i kobiet (Darska, 2011, s. 12). Literaturę popularną zazwyczaj ignoruje krytyka literacka, co jest podejściem niesłusznym, gdyż gatunek ten pozwala na diagnozę istotnej przestrzeni społecznej. Darska zwraca także uwagę, że krytyczne czytanie literatury popularnej udowadnia, że znajdują się w niej bardzo ambitne przesłania i treści, których nikt się spodziewa (Darska, 2011, s. 15).

Bohaterki powieści kryminalnych prowadzące śledztwo można podzielić na dwie grupy: kobiety zajmujące się dochodzeniem zawodowo (policjantki, milicjantki, dziennikarki śledcze, profilerki, psycholożki, lekarki zajmujące się ciałami zmarłych) oraz postaci kobiece, które próbują rozwikłać przestępstwo i zidentyfikować mordercę, ale nie ma to nic wspólnego z ich aktywnością zawodową, raczej z czystą ciekawością czy hobby (Darska, 2011, s. 15). Róża Kwiatkowska sytuuje się pomiędzy tymi grupami, jest dziennikarką w „Chorzowskich Nowinach", nie zajmuje się jednak tematyką kryminalną, a morderstwo dokonane w zamieszkanej przez nią kamienicy traktuje jako szansę zdobycia upragnionego awansu i sławy. Pośrednią przyczyną zainteresowania dziennikarki krwawym morderstwem, poza oczywiście niezdrową wrodzoną ciekawością, jest jej nowy sąsiad, a stary znajomy, wspomniany już Szymon Solański. Były policjant podejmuje śledztwo dotyczące śmierci Marianny Biel powodowany ciekawością, ale także chęcią wykazania się przed byłymi kolegami z jednostki policyjnej, których uważa za niekompetentnych.

Praca dziennikarska satysfakcjonuje Różę. Jej wścibskie natręctwo pozwala na bezwstydne poszukiwanie i drążenie ciekawych tematów. Zawód ten jest także ucieczką od rodzinnych problemów - rodzice bohaterki są sławnymi chirurgami z manią wyższości, a córkę uważają za pomyłkę i uosobienie zawiedzionych ambicji. Kwiatkowska byłaby nikim bez swojej przekory i buntu — tak więc najważniejsze życiowe decyzje podejmuje wiedziona właśnie tymi emocjami. Odmawia realizacji marzeń i oczekiwań rodziców stawianych wobec niej, dotyka finansowego dna, uparcie trzymając się własnych przekonań. Postać Kwiatkowskiej można w pewnych aspektach porównać do kreacji Anniki Bengtzon, bo- 
haterki popularnej serii Lizy Marklund. Bengtzon, tak jak Kwiatkowska, uciekła od swoich rodziców, trwając w przekonaniu, że dalsza egzystencja w rodzinnym mieście sprowadza się do zamknięcia jej w klatce typowej dla żony i matki. Rzuca się na głęboką wodę, wyprowadza do Sztokholmu i próbuje realizować swój plan. Mieszka w spartańskich warunkach - w kamienicy przeznaczonej do rozbiórki, bez łazienki, bez ogrzewania i ciepłej wody. Jednak ani ta, ani inne życiowe przeszkody nie stanowią dla niej większego problemu. Róża prezentuje ten sam typ: prze naprzód jak taran, z właściwym sobie brakiem wdzięku i taktu, rozwalając kłody rzucane pod jej nogi, czasem wręcz budując z nich schody.

Życie uczuciowe Kwiatkowskiej jest zawiłe i skomplikowane. Róża zachowuje się w absurdalny sposób, pozwala emocjom brać górę nad rozsądkiem, nie radzi sobie ze swoimi doznaniami. W osiągnięciu spokoju umysłowego przeszkadza jej przekorny i buntowniczy charakter; gdy tylko sprawy mają szansę się ułożyć, kobieta wszystko psuje swoim uporem. Bohaterka ta jest postacią komiczną w powieści kryminalnej o dużym zabarwieniu komicznym, dlatego perypetie, w jakie popada, są ujęte $\mathrm{z}$ odpowiednim dystansem. Róża pomimo wstrętnego charakteru ma dobre serce, wykazuje lojalność wobec swoich przyjaciół (bezustannie dokarmia Gucia, co jest kamieniem węgielnym ich przyjaźni) i stara się pomagać osobom potrzebującym.

Portretując kreację Róży Kwiatkowskiej, zwykle mówi się o cechach negatywnych. Dlaczego więc dziennikarka w trakcie lektury wzbudza sympatię i rozbawienie? Ogromną rolę w tej kwestii odgrywa aspekt komiczny, sposób, w jaki opisuje się Różę. Zdaje się, że jej postać jest kolażem wielu kobiet, a w jej charakterze każda może odnaleźć coś z siebie. W przeciwieństwie do „typowych” (jeżeli obecna mnogość charakterów pozwala na użycie tego słowa) bohaterek powieści kryminalnych Róża nie jest „mistrzynią w męskim świecie”. W zasadzie nie wyróżnia się niczym. Nie wolno zapomnieć, że pomimo rozpaczliwie nieatrakcyjnej aparycji oraz „męskiego” zachowania Róża to kobieta, co więcej, pomimo różnych wpadek jest kobietą dumną, która w razie potrzeby bierze sprawy w swoje ręce i nie boi się wyzwań, jakkolwiek opłakane byłyby ich skutki. Dziennikarce „brak” talentu, który pozwoliłby jej zabłysnąć, a przez życie prowadzą ją niezdrowy upór i serie niefortunnych zdarzeń. Róża jest pozytywną antybohaterką, ponieważ wizualizuje każdą kobietę zaplątaną w wir codziennych zdarzeń.

A teraz pies. Przydługa prezentacja dwojga bohaterów ma dowodzić, że Gucio jako ten trzeci został potraktowany w sposób równorzędny z ludzkimi postaciami. Warto wspomnieć, że powieść stanowi swoisty hołd złożony przez autorkę swojemu ulubieńcowi; wszak psi detektyw ma swój pierwowzór w prawdziwym psie należącym do Matyszczak.

Gucio jest kundelkiem z urodzenia, psem zaczepno-obronnym $\mathrm{z}$,wykształcenia” i „tropicielem kiełbasy”. Brakuje mu jednej łapy, co tylko dodaje mu uroku oraz siły perswazji w zdobyciu tego, czego chce. Solański adoptuje go ze Schroniska dla Bezdomnych Zwierząt w Chorzowie, wcześniejsze losy psa pozostają nie- 
znane. Gucio w ironiczny i zabawny sposób komentuje decyzje właściciela i innych postaci, a także bierze czynny udział w śledztwie, korzystając ze swojego uroku osobistego i prowadząc obserwacje z miejsc niedostępnych człowiekowi.

Gucio opisuje swoją aparycję w następujący sposób:

Pomijałem milczeniem fakt, że gdyby wykazał się choć odrobiną inteligencji, mógłby skorzystać z mojego nieodpartego uroku osobistego [...]. Nie przechwalając się, moja uroda aż biła po oczach, powalała na kolana, a niedowiarkom dawała po pysku już przy drugim spojrzeniu. Miałem brązowe ślepia, nie jakieś zszarzałe jak Szymon. Dysponowałem czarnym niczym węgielek nosem. Uszka miałem jak haczyki. Klapnięte, jednak w razie potrzeby mogłem postawić je na sztorc. Jasnobrązowe były moje łapy, krawatka i brzuch. Reszta futra lśniła czernią. Ogon miałem karbowany i wcale nie musiałem w tym celu używać prostownicy ze specjalną nasadką. Tyle o mnie. Nie chciałbym, żebyście wzięli mnie za narcyza.

Kundelek jest jednym z dwóch przyjaciół Solańskiego, toteż bardzo się o niego troszczy, kwestionując jego zdrowy rozsądek i każdą decyzję. Jest pozytywnym bohaterem i aktywnym śledczym. Portretując zwierzęcego bohatera w powieści Tajemnicza śmierć..., warto wspomnieć o przytoczonym wcześniej czytaniu ekokrytycznym w odniesieniu do animal studies. Historię psa, który żyje życiem swojego opiekuna, troszczy się o niego i pomaga mu rozwiązywać zagadki kryminalne, można zinterpretować jako materiał do dyskusji o relacjach międzygatunkowych i konieczności rozstania się z antropocentryczną wizją świata. Powieść, której bohaterem jest kundelek Gucio, ma w sobie element dydaktyczny dotyczący relacji człowiek - pies. Kundelek opowiada o swoich doświadczeniach ze schroniska, o ludzkim konsumpcjonizmie powiązanym $\mathrm{z}$ chęcią posiadania pięknego rasowego pieska, co kończy się wysypem pseudohodowli i niesamowitym cierpieniem zwierząt. Tajemnicza śmierć... może być zachętą do refleksji ekologicznej, polegającej na ujrzeniu w zwierzęciu istoty, która zasługuje na szacunek w równym stopniu, co człowiek (Gralewicz-Wolny, 2016, s. 316).

Gucio zostaje zaprezentowany zarówno z typowo zwierzęcej strony - zamiłowania do kiełbasy śląskiej i „schaboszczaków”, jak i ludzkiej — troszczy się o Szymona, denerwuje, na swój sposób „mówi”, nie zawsze będąc zrozumianym, umie nawet liczyć. Opisy każdej z natur kundelka są wymieszane i niejednoznaczne, zabarwione jego typowym poczuciem humoru:

Jak na przykładnego kundla przystało, potrafiłem rachować do pięciu. Dobrze, że na tym kończyły się moje zdolności matematyczne, bo jeszcze bym się doliczył, która to już jesień mijała mi w schronisku. Na pewno nie pierwsza, a jak lubiłem powtarzać, użalając się nad sobą - być może ostatnia. 
Gucio porozumiewa się z ludźmi na swój zantropomorfizowany sposób. Przekazuje swoje pragnienia, a także uwagi, które jego opiekunowie zazwyczaj odbierają nie tak, jakby sobie tego życzył:

Walnąłem Solańskiego łapą w piszczel na znak porozumienia. Spojrzał na mnie stalowym wzrokiem siwych oczu i... wyciągnął z kieszeni parówkę. Powiedzcie sami, czy byście takiego nie pokochali od zaraz? Zeżarłem dar, nawet nie siląc się na przeżuwanie.

Kundelek ma określone poglądy na ludzi. Pewnych kocha od razu, natomiast innych nie cierpi z całego serca:

Musiał się dopiero nauczyć ten człekokształt, że być może mam początki całej tej zaćmy, czasem słyszę tylko to, co chcę słyszeć, ale nos nie zawiódł mnie jeszcze nigdy.

Motywy zwierzęce w literaturze, nie tylko kryminalnej, są powszechnie wprowadzane od wielu lat. Nawet jeżeli nie odgrywają kluczowej dla fabuły roli, to umożliwiają lepsze scharakteryzowanie postaci, tworzą klimat, a czasem pozwalają na włączenie elementów humorystycznych lub abstrakcyjnych. Psy pojawiają się w utworach kryminalnych wyjątkowo często ze względu na naturalnie posiadane zdolności - inteligencję, umiejętność tropienia, poszukiwania i współpracy z człowiekiem. Z pewnością jednym z najbardziej znanych motywów w powieściach kryminalnych jest ten dotyczący psiego detektywa - pies detektyw stanowiący składową zespołu „człowiek i zwierzę”, jego dopełnienie, bez którego nie jest w stanie funkcjonować ani pracować na tak wysokim poziomie jak w duecie. W pewnym sensie pies śledczy był uosobieniem braków człowieka - pies Jip w serii o Doktorze Dolittle mówi o wąchaniu:

Gorąca woda pachnie zupełnie inaczej niż zimna. Ciepła woda albo lód te dopiero mają trudny do rozpoznania zapach! Kiedyś ciemną nocą przez dziesięć mil szedłem śladem pewnego człowieka. Nie zgubiłem go, bo pachniał gorącą wodą, której używał do golenia, biedaka bowiem nie było stać na mydło...

Lofting, 2010, s. 10

Sam doktor Dolittle zdaje sobie sprawę ze źródłowej różnicy kompetencji, zmysłowej niekompatybilności, rozmaitych zdolności charakteryzujących zwierzęcą społeczność. Najważniejsze we współpracy psa i człowieka są zachowanie i docenienie różnic przy jednoczesnym pragnieniu komunikacji (Mytych-Forajter, 2016, s. 330). Literatura oferuje wiele książek, gdzie dochodzenie pro- 
wadzi duet: pies i człowiek, a rozwiązanie zagadki byłoby niemożliwe bez elementu zwierzęcego.

Myśląc o postaci psiego detektywa, nasuwa nam się na myśl wiele literackich postaci. Abstrahując od Scooby'ego Doo, najsłynniejszego czworonożnego śledczego popkultury, literatura przedstawia nam cały wachlarz tego typu bohaterów czynnie biorących udział w dochodzeniu.

W polskiej serii dla młodzieży autorstwa Joanny Chmielewskiej pojawia się pies Chaber, nazwany na cześć nazwiska jego nowych opiekunów - rodzeństwa Chabrowiczów, Pawła i Janeczki, niezwykle inteligentnych i wesołych dzieci. Seria ta, podobnie jak książki należące do cyklu Kryminat pod psem, bywa określana jako „kryminał na wesoło”. Chaber jest psem wyszkolonym, bardzo wrażliwym na zapachy, dźwięki i obcych ludzi:

— Coś podobnego, to jest myśliwski pies! — wykrzyknął zaskoczony. Popatrzcie, jak pięknie wystawia kuropatwę!

- Gdzie jest ta kuropatwa? - zainteresował się Pawełek.

- Nigdzie, ale przyjrzyj mu się. To jest charakterystyczna poza myśliwskiego psa, który daje znak, że coś zwęszył. Musiał być doskonale tresowany.

Chmielewska, 1993, s. 22

Pies pomaga dzieciom rozwiązywać złożone zagadki kryminalne, staje się wręcz osią fabuły. Bez Chabra nie ma śledztwa. Chaber, podobnie jak Gucio, został przygarnięty ze schroniska, a dzięki Janeczce i Pawełkowi staje się członkiem rodziny, który poniekąd „zarządza” jej członkami, wykonując polecenia przedsiębiorczego rodzeństwa. Cała seria o rodzeństwie Chabrowiczów ma lekki i przyjemny charakter, łatwo się ją czyta, a zabawnie opisane postacie oraz ich perypetie na długo pozostają w pamięci.

Innym psim bohaterem, „wielkopsem”, jest dog niemiecki Protazy występujący w książce Pan Samochodzik i tajemnica tajemnic. W tej powieści, będącej częścią serii kryminalnej o historyku sztuki tropiącym przemyt czy kradzież dzieł, psiemu bohaterowi zostają nadane ludzkie cechy i zachowania, które niewiele wspólnego mają z rzeczywistością, ale wprowadzają zabawny nastrój i elementy komiczne:

Potężne zwierzę, które przez cały czas naszej rozmowy nie przestawało mnie czujnie obserwować, raptem przysiadło na zadzie i wyciągnęło do mnie wielką łapę.

- Co on chce? - zapytałem.

- Pan nie rozumie? Zdecydował się z panem przywitać - wyjaśniła gospodyni.

Z obawą ująłem w dłoń szorstką łapę i potrząsnąłem nią kilkakrotnie, jakbym witał się ze znajomym. 
Pan Samochodzik wpada na trop szajki zajmującej się przemytem ikon. Na skutek zbiegu okoliczności zgadza się zaopiekować „pieskiem” znajomego, który okazuje się ogromnym dogiem rozmiaru małego cielaka. Tomasz NN, czyli tytułowy Pan Samochodzik, przywiązuje się do Protazego, zabiera go z sobą w służbowe podróże, czując wyrzuty sumienia na samą myśl o porzuceniu psa. Tak jak w poprzednich przypadkach, również tutaj psi bohater ma ogromny wpływ na fabułę i bieg wydarzeń, a jego olbrzymie rozmiary są źródłem wielu komicznych sytuacji oraz utrudnień w śledztwie.

Twórcy powieści kryminalnych bardzo często przywołują motyw zwierzęcy - psiego detektywa. Zdolności psa są zestawione ze zdolnościami człowieka, zwierzęta operują niesamowitym węchem, wzrokiem, słuchem, a ludzkie zdolności w tym zakresie wydają się ułomne. Nie można także z całą pewnością odebrać psom detektywom pewnej zdolności dedukcyjnego myślenia, łączenia informacji, jak choćby zapachu osoby z innymi jej cechami.

Zestawienie dwóch całkiem odmiennych istot może być pytaniem o istotę zwierzęcości. Odpowiedź na to pytanie oparta na wiarygodnych badaniach pozwoliłaby wyznaczyć granicę między ludzkim a zwierzęcym bądź przeciwnie całkowicie unieważnić tę obecnie istniejącą (Czaja, 2009). Warto więc zastanowić się nad istotą człowieczeństwa, nad znaczeniem różnic i podobieństw między światem zwierzęcym i ludzkim, a także nad relacjami między nimi. Wywiązuje się spór: czy „nadwyżka” znana jako „kultura” ma umocowanie w biologii, czy też może jest dodatkiem z przypadku, niesprowadzonym do genetycznych uwarunkowań (Czaja, 2009). Dariusz Czaja odpowiada w ten sposób:

Bez wątpienia, nic nie stoi na przeszkodzie, by wierzenia religijne, normy moralne czy twórczość artystyczną wyinterpretować w terminach animalnej natury i uznać za czynności adaptacyjne, które gatunkowi ludzkiemu pozwalają przetrwać i bronić się przed zagrożeniami zewnętrznymi. Ale interpretacja tego typu nie jest metodologicznie niewinna; wbrew temu, co sądzą jej autorzy, nie jest prostą indukcją z faktów. Dobrze tedy pamiętać, że [...] czym innym jest twierdzić, że ludzkie sposoby zachowania są genetycznie zakorzenione we własnościach niższych gatunków, a czym innym głosić, że te pierwsze są niczym innym, jak tymi drugimi.

Czaja, 2009

Zdaje się, że tworzenie duetów zwierzęco-ludzkich, wykazujących sprawność tylko dzięki wspólnej pracy, jest próbą odzewu na pytanie o istotę zwierzęcości. Odkąd istnieje literatura, zwierzętom nadawało się pewne typowo ludzkie cechy, niemające usprawiedliwienia w świecie fauny. Powstały zwierzęce alegorie i symbole, zwierzęcy bohaterowie stali się sławni i legendarni, a mimo to, mimo ewolucjonistycznych badań, granica pozostaje rozmyta i niedookreślona. Problem w jej określeniu leży w ludzkiej naturze i związanym z nią poczuciu wyższości nad nie-ludzkimi bytami (Kowalczyk, 2009): albo zakładamy, że wiemy, jak to 
jest być inną istotą, albo po prostu nie stawiamy sobie takiego pytania. W zamian za to od wieków zastanawiamy się, jak to jest być człowiekiem, i skupiamy na poglądzie antropocentrycznym. Upodmiotowienie zwierząt wiąże się z uznaniem ich świadomości, a także świadomości odczuwania bólu. Kartezjańską maksymę „myślę, więc jestem”, przeformułowaliśmy w „cierpię, więc jestem” (Kowalczyk, 2009). Mimo to cierpienie postrzegamy w sposób subiektywny dla danego gatunku, a naszą perspektywę uznajemy za obiektywną, pomijamy fakt, że nikt tak naprawdę się nie dowie, jak cierpi świnia. Warunkiem upodmiotowienia staje się ocena jaźni zwierząt własną miarą. Brak dotąd dokładniejszych i rzetelniejszych narzędzi pozwalających przyjąć zwierzęcą perspektywę, ale należy sobie zdawać sprawę z niedoskonałości takiego myślenia. Oceniając zwierzęcą świadomość jako „wystarczającą” do przyznania jej kategorii podmiotu, przywołujemy "ludzkie” cechy zwierząt - świnia ma świadomość odpowiadającą trzylatkowi, konie - dwulatkowi. Antropomorfizując zwierzęta, nadając im ludzkie cechy, lekceważymy ich odrębność i podtrzymujemy przekonanie, że warunkiem upodmiotowienia jest dostrzeżenie w Innym ludzkich cech (Kowalczyk, 2009). Należy wziąć pod uwagę, że krowa czy koń cierpią inaczej niż ludzie, nigdy nie dowiemy się naprawdę jak, ale nasz brak wiedzy na ten temat nie umniejsza podmiotowości zwierząt oraz konieczności traktowania ich jako jednostek zasługujących na szacunek.

Dwóch francuskich filozofów Gilles Deleuze i Felix Guattari prezentuje typologię „stawania-się-zwierzęciem” (Deleuze, Guattari, 2015): zwierzęta domowe - podopieczni człowieka, w których odkrywamy ludzkie cechy, to kategoria zwierząt niedoceniana i deprecjonowana przez autorów; następnie zwierzęta, które prezentują wzorce i atrybuty nadane im przez człowieka, stały się nieodłączną częścią mitów i wierzeń, oraz zwierzęta dzikie, żyjące na wolności, niezależne od człowieka, tworzące demoniczną narrację. Autorzy dopuszczają myśl, że zwierzęta mogą przemieszczać się z jednej kategorii do drugiej.

Agata Araszkiewicz w tekście Zwierz-am się, więc jestem (Araszkiewicz, 2007, s. 154) również bierze pod uwagę ludzkie stawanie się zwierzętami, co można odnieść do powieści z udziałem psa detektywa. Wspomina, że tradycja filozoficzna, w której żyjemy, od zawsze odmawiała zwierzętom statusu równości wobec człowieka, wykazując ich braki i niedoskonałości względem naszego gatunku. Guattari i Deleuze przekroczyli granicę antropocentryzmu, mówiąc, że nasze relacje ze zwierzętami nie mogą być ludzkie, bo są właśnie zwierzęce. Człowiek, żyjąc $w$ tak bliskim związku ze zwierzęciem, tworzy z nim stado. W stadzie jednak panuje hierarchia oparta na komunikatach. Araszkiewicz zauważa, że w pewnym sensie nasza zwierzęcość staje się tak dojmująca, że zaczyna przerażać, dlatego staramy się temu zaprzeczać (Araszkiewicz, 2007, s. 156). Wtedy zaczynamy poszukiwać nowych granic między człowiekiem a zwierzęciem. Zadając pytanie o istotę bycia, już na początku pozbawia się zwierzę "głosu”, a jego podmiotowość i język we własnej sprawie zostają skonfiskowane. W tradycji filozoficznej 
rozważania na temat antropologicznej granicy nabierały charakteru „przesłuchań" zwierząt, pytań o ich posiadane zdolności, dzięki którym mogłyby w jakiś sposób zaistnieć w języku. Wielu filozofów pytało, „czy zwierzę potrafi myśleć, rozumować, opanowywać technikę, a zwłaszcza mówić - wyrażać i naśladować logos za pomocą znaków, rozumnego dyskursu, który byłby uchwytny także dla istoty ludzkiej" (Koza, 2014, s. 163-170).

Uprzedmiotowienie zwierząt zaczyna się już w języku:

Zwykle używamy słowa „Zwierzę” w znaczeniu: „Zwierzę inne niż człowiek”. Ten sposób mówienia separuje człowieka od innych zwierząt, sugerując, że my nimi nie jesteśmy — wniosek, którego fałsz jest oczywisty dla każdego, kto choćby tylko w szkole podstawowej uczył się biologii.

Singer, 2004, s. 11

Proces upodmiotowienia zwierząt nie przebiega więc tylko wskutek działań aktywistów, przechodzenia na wegetarianizm czy weganizm albo „otwierania klatek"; zachodzi również na poziomie pielęgnowania języka. Język nie tylko opisuje, ale również kształtuje rzeczywistość.

Znaczenie mają właśnie pozornie drobne wybory, jak ten, czy mówimy o „opiekunie” czy „właścicielu” psa albo o „zdychaniu” czy „umieraniu” kota. Za językiem kryją się nasze zaniedbania, tak samo jak lęki i przedmioty wyparcia. Dystans etyczny, który stoi za tym, że nie chcemy dostrzec w sobie „psychopatycznego oprawcy” ani zauważyć „krwi na własnych rękach”, również znajduje swoje odzwierciedlenie w języku - w końcu nie jemy krowy ani świni, ale wołowinę lub wieprzowinę.

Kowalczyk, 2019

Araszkiewicz podsumowuje dyskusję w następujący sposób: „nie chodzi o to, aby oddać zwierzętom głos, ale o to, by nie traktować ich nieobecności mowy jako braku" (Araszkiewicz, 2007, s. 154).

Wydaje się, że głos badaczki może być na tyle inspirujący, że warto go wziąć pod uwagę podczas lektury tekstów dla dorosłych i niedorosłych adresatów, których wspomnienie nie będzie dotyczyło jedynie Ignacego Rzeckiego, ale również jego psa Ira, którego imię to przecież inicjały starego subiekta. Pamiętajmy więc o Ferdynandzie Wspaniałym i innych wielkich kreacjach nie-ludzkich istot.

\section{Literatura}

Araszkiewicz A., 2007, Zwierz-am się, więc jestem, „Czas Kultury”, nr 6, s. 154-156.

Barcz A., Łagodzka D., 2015, Wstęp. O świecie więcej niż ludzkim, w: Bednarek J.B., Gostyński D., Czapliński P., red., Zwierzęta i ich ludzie. Zmierzch antropocentrycznego paradygmatu. Warszawa, s. 7-13. 
Berger J., 1999, O patrzeniu, Sikora S., przeł., Warszawa.

Burszta W., Czubaj M., 2007, Krwawa setka. 100 najważniejszych powieści kryminalnych, Warszawa.

Chmielewska J., 1993, Nawiedzony dom, Łódź.

Cieślikowski J., 1975, Literatura i podkultura dziecięca, Wrocław.

Czaja D., 2009, Zwierzęta w klatce (języków). https://www.gnosis.art.pl/e_gnosis/punkt_ widzenia/czaja_zwierzeta_w_klatce_jezykow_01.htm [data dostępu: 20.03.2019].

Czubaj M., 2007, Krwawa setka, Warszawa.

Darska B., 2011, Śledztwo i płeć. O bohaterkach powieści kryminalnych, t. 1, Olsztyn.

Deleuze G., Guattari F., 2015, Kapitalizm i schizofrenia II: Tysiąc plateau, Warszawa.

Domańska E., 2006, Historie niekonwencjonalne, Poznań.

Eco U., 2009, Od drzewa do labiryntu. Studia historyczne o znaku i interpretacji, Jurkowlaniec G., przeł., Warszawa.

Gralewicz-Wolny I., 2015, Tę książkę wymyślił pies..., w: Niesporek-Szamburska B., Wójcik-Dudek M., Zok-Smoła A., red., (Przed)szkolne spotkania z lektura, Katowice, s. 315-324.

Kowalczyk Z., 2019, Skąd wiesz, że pies cierpi?, „Pismo”, nr 2. https://magazynpismo.pl/ wszyscy-jestesmy-zwierzetami-pies/ [data dostępu: 27.03.2019].

Koza M., 2014, Śladem różnicy. Dekonstrukcja granicy między człowiekiem a zwierzęciem $w$ filozofii Jacques'a Derridy, w: Tymieniecka-Suchanek J., red., Człowiek $w$ relacji do zwierząt, roślin i maszyn w kulturze, t. 1: Aspekt posthumanistyczny i transhumanistyczny, Katowice, s. 163-170.

Kurek J., Maliszewski K., 2011, Wstęp, w: Kurek J., Maliszewski K., red., Zwierzęta i ludzie. Chorzów.

Lestel D., 2015, Myśleć sierścią. Zwierzęcość w perspektywie drugoosobowej, w: Barcz A., Łagodzka D., red., Zwierzęta $i$ ich ludzie. Zmierzch antropocentrycznego paradygmatu, Warszawa, s. 17-33.

Lofting H., 2010, Doktor Dolittle i jego zwierzęta, Adamczyk B., przeł., Poznań.

Matyszczak M., 2017, Tajemnicza śmierć Marianny Biel, Wrocław.

Mytych-Forajter B., 2015, Doktor Dolittle i jego zwierzęta - lektura ekokrytyczna, w: Niesporek-Szamburska B., Wójcik-Dudek M., Zok-Smoła A., red., (Przed)szkolne spotkania z lektura, Katowice, s. 325-334.

Nawarecki A., 2011, Zoofilologia, w: Kurek J., Maliszewski K., red., Zwierzęta i ludzie, Chorzów, s. 15-17.

Nienacki Z., 1983, Pan Samochodzik i tajemnica tajemnic, Olsztyn.

Nowak K., 2009, Animal studies - wyzwanie dla historiografii?. https:/histmag.org/Ani mal-studies-wyzwanie-dla-historiografii-3208 [data dostępu: 11.02.2019].

Sadzikowska L., 2015, Nowe propozycje lekturowe. Powieść detektywistyczna w szkole podstawowej - o wybranych książkach słów kilka..., w: Niesporek-Szamburska B., Wójcik-Dudek M., Zok-Smoła A., red., (Przed)szkolne spotkania z lektura, Katowice, s. $451-460$.

Singer P., 2004, Wyzwolenie zwierząt, Alichniewicz A., Szczęsna A., przeł., Warszawa.

Żychliński A., 2015, w: Barcz A., Łagodzka D., red., Zwierzęta i ich ludzie. Zmierzch antropocentrycznego paradygmatu, Warszawa, okładka. 
Tatiana Szulik-Opala - absolwentka filologii polskiej na Uniwersytecie Śląskim w Katowicach. Pracuje z dziećmi i młodzieżą, zarówno w szkole podstawowej, jak i liceum ogólnokształcącym. Jej zainteresowania badawcze związane są z szeroko pojętą dydaktyką nauczania języka polskiego, obejmują również tematykę animal studies.

e-mail: tatianaszulik@hotmail.com 